\begin{tabular}{|l|l|}
\hline $\begin{array}{l}\text { Instituto de } \\
\text { Geriatria e Gerontologia }\end{array}$ & $\begin{array}{l}\text { Pan American Journal of Aging Research } \\
\text { PAJAR, Porto Alegre, v. 9, p. 1-11, jan.-dez. } 2021 \\
\text { ISSN-L: 2357-9641 }\end{array}$ \\
\hline http://dx.doi.org/10.15448/2357-9641.2021.1.40223 & \\
\cline { 2 - 3 }
\end{tabular}

\title{
Does the psychological variables predict life satisfaction and purpose in life in brazilian elderly?
}

\author{
Variáveis psicológicas predizem a satisfação e propósito de vida em idosos brasileiros? \\ ¿las variables psicológicas predicen la satisfacción y el propósito de la vida en las \\ personas mayores brasileñas?
}

\section{Daniel Vicentini de Oliveira ${ }^{1}$ orcid.org/0000-0002-0272-9773 d.vicentini@hotmail.com}

Renan Codonhato ${ }^{2}$ orcid.org/0000-0003-1061-7111 gperenan@gmail.com

\section{Matheus Amarante do}

Nascimento ${ }^{3}$

orcid.org/0000-0002-4677-8956 matheusamarante@hotmail.com

Braulio Henrique Magnani

Branco $^{1}$

orcid.org/0000-0002-4625-9128

braulio.branco@unicesumar.edu.br

\section{Gabriel Lucas Morais Freire ${ }^{2}$}

orcid.org/0000-0003-0589-9003 bi88el@gmail.com

\section{José Roberto Andrade do}

Nascimento Júnior ${ }^{4}$

orcid.org/0000-0003-3836-6967

jroberto.jrs01@gmail.com

\section{Lenamar Fiorese ${ }^{5}$}

orcid.org/0000-0003-1610-7534 lenamarfiorese@gmail.com

Received on: Feb. 25th, 2021 Accepted on: Jul. 14th, 2021 Published on: Aug. 26th, 2021

\begin{abstract}
Aims: the present study aimed to investigate the association between indicatives of stress, anxiety and depression with life satisfaction and purpose in life among Brazilian older adults.

Methods: this cross-sectional study was conducted with 654 Brazilian older adults who responded the Life Satisfaction Scale, Purpose in Life Scale, Perceived Stress Scale, Geriatric Anxiety Inventory and the Geriatric Depression Scale. Data were analyzed through independent t-test, Cohen's D. Pearson Correlations and Multivariate Regression Analysis ( $p<0.05)$.

Results: results indicated slightly higher levels of stress and anxiety for women when compared to men $(p<0.05)$; indicatives of stress, anxiety and depression were inversely correlated to life satisfaction and purpose $(r=-0.19$ to -0.44 ; $p<0.05)$; stress $(\beta=-0.29)$ and depression $(\beta=-0.36)$ were significant predictors of life satisfaction $\left(R^{2}=0.31 ; p<0.01\right)$, and life purpose $\left(R^{2}=0.18 ; p<0.01\right)$ was predicted by stress $(\beta=-0.15)$, anxiety $(\beta=0.10)$ and depression $(\beta=-0.39)$.

Conclusion: It can be concluded that stress and depression are significant factors hindering older adults' satisfaction and purpose in life.

Keywords: aged, depression, emotional stress, personal satisfaction.

\section{Resumo}

Objetivo: o presente estudo teve como objetivo investigar a associação entre indicativos de estresse, ansiedade e depressão com a satisfação e propósito de vida em 654 idosos brasileiros.

Métodos: estudo transversal, o qual foi utilizada a Escala de Satisfação com a Vida, Escala de Propósito de Vida, Escala de Estresse Percebido, o Inventário de Ansiedade Geriátrica e a Escala de Depressão Geriátrica. Os dados foram analisados por meio do teste t independente, D de Cohen, Correlações de Pearson e Análise de Regressão Multivariada.

Resultados: os resultados apresentaram niveis ligeiramente superiores de indicativo de estresse e de ansiedade para o sexo feminino $(p<0,05)$; indicativos de estresse, ansiedade e depressão foram inversamente correlacionados à satisfação com a vida e propósito de vida $(r=-0,19$ a $-0,44 ; p<0,05)$; indicativo de estresse $(\beta=-0,29)$ e de depressão $(\beta=-0,36)$ foram preditores significativos de satisfação com a vida $(R 2=0,31 ; p<0,01)$; propósito de vida $(R 2=0,18 ; p<0,01)$ foi predito pelo indicativo de estresse $(\beta=-0,15)$, ansiedade $(\beta=0,10)$ e depressão $(\beta=-0,39)$.
\end{abstract}

\section{(c) (1)}

Artigo está licenciado sob forma de uma licença Creative Commons Atribuicãa 4.0 Internacional.

\footnotetext{
Cesumar University (Unicesumar), Maringá, PR, Brazil.

Maringá State University (UEM), Maringá, PR, Brazil.

Paraná State University (UNESPAR), Paranavai, PR, Brazil.

São Francisco Valley Federal University, Petrolina, PE, Brazil.

Maringá State University, Maringá, PR, Brazil.
} 
Conclusão: pode-se concluir que o indicativo de estresse e de depressão são fatores significativos que dificultam a satisfação e o propósito de vida dos idosos.

Palavras-chave: idoso, depressão, estresse emocional, satisfação pessoal.

\section{Resumen}

Objetivo: el presente estudio tuvo como objetivo investigar la asociación entre los indicadores de estrés, ansiedad y depresión con la satisfacción y el propósito de la vida en 654 ancianos brasileños.

Métodos: estudio transversal, que utilizó la Escala de Satisfacción de Vida, la Escala de Propósito de Vida, la Escala de Estrés Percibido, el Inventario de Ansiedad Geriátrica y la Escala de Depresión Geriátrica. Los datos se analizaron mediante la prueba t independiente, $\mathrm{D}$ de Cohen, correlaciones de Pearson y análisis de regresión multivariante.

Resultados: los resultados indicaron niveles ligeramente más altos de estrés y ansiedad para las mujeres ( $p<0.05$ ); los indicios de estrés, ansiedad y depresión se correlacionaron inversamente con la satisfacción con la vida y el propósito de la vida $(r=-0,19$ a $-0,44 ; p$ $<0,05)$; indicativo de estrés $(\beta=-0,29)$ y depresión $(\beta=$ $-0,36)$ fueron predictores significativos de satisfacción con la vida ( $R 2=0,31 ; \mathrm{p}<0,01)$; El propósito de la vida $(R 2=0.18 ; p<0.01)$ fue predicho por indicativo de estrés $(\beta=-0.15)$, ansiedad $(\beta=0.10)$ y depresión $(\beta=-0.39$ ).

Conclusión: se puede concluir que los indicativos de estrés y depresión son factores significativos que dificultan la satisfacción y el propósito de vida de las personas mayores.

Palabras clave: anciano, depresión, estrés emocional, satisfacción personal.

\section{Introduction}

The world population is aging, and the perspective, according to the World Health Organization, is that in 2050 one in five people will be elderly, which will account for about 2 billion individuals over 60 years old worldwid ${ }^{1}$. In Brazil, it is estimated that in 2050 life expectancy will be around 80 years old, which, in turn, will lead the older adult population to be greater than the younger population (0-14 years old) ${ }^{2}$. Along with the aging process comes a series of consequences such as changes in body composition usually associated with reductions in muscle strength ${ }^{3}$, loss of autonomy ${ }^{4}$, increased number of falls and fractures ${ }^{5}$, reduced bone mineral density ${ }^{6}$, and sometimes even leading to frailty, functional incapacity and premature death?

In addition, social, and psychological changes may also play an important role on aging, and consequently, on health and quality of life of older people ${ }^{8}$. Depression and anxiety, for example, might negatively impact health outcomes (e.g. stroke, coronary heart disease, and myocardial infarction ${ }^{9-10}$ ), not to mention the important role of positive psychiatry in reducing mental disorders and promoting a healthy aging ${ }^{11}$. In this sense, understanding and promoting successful aging is of extreme importance to health professionals and the overall population.

The core elements of successful aging have been described as maintaining both good physical and cognitive health, engaging in productive activities and having good social relationships, for example, through active engagement with other people ${ }^{12}$. In a wider sense, successful aging is a product of one's overall health, quality of life and satisfaction with life ${ }^{13}$. Thus, life satisfaction is considered essential for successful aging ${ }^{14}$.

Life satisfaction is a relatively stable indicator of one's orientation towards life ${ }^{15}$, it is widely accepted as a fundamental aspect of human welfare and perceived quality of life ${ }^{16}$, having being increasingly used by researchers to study well-being and quality of life ${ }^{14,17,18}$ in older populations. Such construct has even predicted fatal injury, mortality risk ${ }^{19}$ and mortality over time $^{20}$ in elderly populations. One interesting thing about life satisfaction is that happy people usually tend to live longer ${ }^{21,22}$.

Literature concerning life satisfaction predictors have addressed social aspects (e.g. social relationships and social support) ${ }^{18.23-29}$, personality traits and physical activity ${ }^{16}$, leisure physical activities ${ }^{13}$, self-rated measurements of health ${ }^{23,24,27,30,31}$ and psychological well-being ${ }^{32}$. Nonetheless, the understanding of factors hindering life satisfaction is still limited and there is still a literature gap regarding the relationship between anxiety, stress and life satisfaction.

The majority of evidence about factors diminishing older adults' life satisfaction has focused on depression, with depressive symptoms being consistently reported as a negative predictor or life satisfaction ${ }^{16,25,33-37}$. Moreover, anxiety and negative social aspects, such as loneliness ${ }^{10.16 .25}$, and difficulty with affect and with interpersonal activities ${ }^{30}$ were also negatively related to life satisfaction. 
Another important aspect to be considered when looking into successful aging is purpose in life. Purpose in life is considered one key dimension of psychological well-being and represents the belief that life has a meaning, a direction, and that goals are being, or can be achieved ${ }^{38}$. A recent systematic review of purpose in life's literature in older adults ${ }^{39}$ found that purpose in life has been linked to outcomes such as reduced anxiety, loneliness and depression, reduced risk of stroke, infarction and all-cause mortality, reduced risk for Alzheimer disease, lower incidence of sleep disturbances, increased functional status, better self-rated health and well-being, and improved cognition. Greater purpose in life has also been linked to lower risk for type-2 diabetes ${ }^{40}$ and may protect against cognitive decline ${ }^{41}$.

Despite the great body of evidence upon life satisfaction and purpose in life, there is no investigation that focused on stress, anxiety and depression as predictive factors of both life satisfaction and purpose in life in elderly populations. Thus, it is important to better understand the contribution of factors hindering older adults' life satisfaction and their purpose in life in order to develop ways and strategies to enhance these aspects in the elderly. For that matter, the present study had the goal of investigating the association between indicatives of stress, anxiety and depression with life satisfaction and purpose in life among Brazilian older adults.

\section{Methods}

This is an analytical, cross-sectional, and observational study approved by the Ethics Committee of Human by University Center of Maringá, through opinion number 1.777.797/2016.

\section{Participants}

According to data from the Secretary of Health of Maringá, PR, 42,258 older people attended the Basic Health Units (UBS) of the city in 2016. Thus, we used the StatDisk software (version 8.4) to calculate sample size, considering a 95\% confidence level and $4 \%$ of margin of error, adding $10 \%$ of possible losses. The initial sample to be considered was
595 subjects, and the final sample consisted of 654 older people of both sexes. Participants were non-probabilistically and intentionally selected.

The UBSs that older people attended to were subdivided into four regions: East (7 UBS) which covers $21.8 \%$ of the population, northern region (8 UBS) with $34.5 \%$ of the population, western region (8 UBS) with $23.2 \%$ of the population, and south region (8 UBS) that covers $20.4 \%$ of the total older population of the city. Knowing the regions composition, three UBSs were selected by lot to be evaluated in each of the regions. After defining the sample size in each region and selecting the UBSs, it was important to maintain the proportion of older people population in the sample, so the calculations to obtain the final sample by UBS according to gender were proportional to the population.

\section{Instruments}

To characterize older people's sociodemographic profile, a semi-structured questionnaire was used consisting of information regarding age (60 to 69 years, 70 to 79 years, 80 to 90 years), gender (male, female), marital status (married or living with a partner, single, divorced, widower), race (white, black, other), the occupational situation (working or not working for own income), monthly income with minimum wage (MW) in 2016 Census of Brazilian Institute of Geography and Statistics (IGBE) as reference (1 to $2 \mathrm{MW}, 2.1$ to $3 \mathrm{MW}$, more than $3 \mathrm{MW}$ ), retirement (yes, no), schooling (did not study, incomplete elementary school, complete elementary education, complete high school, complete higher education).

The Life Satisfaction Scale, proposed by Diener, Emmons, Larsen \& Griffin ${ }^{42}$ and adapted to Brazil by $\mathrm{Neto}^{43}$, was used to assess life satisfaction. This scale is intended to evaluate how a person is satisfied with his/her own life, being composed of five items, with answers graded according to a Likert-type scale ranging from 1 = totally disagree to 7 = totally agree. The possible total score is 35 points and higher values indicate higher levels of life satisfaction. In the scale adaptation study performed by $\mathrm{Neto}^{43}$, factor analysis showed that all items had high factor loadings on a single 
common factor, and the scale had high reliability. Cronbach's Alpha for the present study was $\alpha=0.72$.

To evaluate purpose in life we adopted the Purpose in Life Scale for Brazilian older adults ${ }^{8}$. The Purpose in Life scale is a self-report instrument with 10 items answered on a Likert-type scale of 5 points in a range from 1 = I strongly disagree to 5 = I strongly agree. To calculate the final score, it is necessary to reverse the score for items 2, 3, 5 . 6 and 10 , then, all items are averaged to obtain a final score which can range from 1 to 5 . Cronbach's alpha for the scale adaptation study was .628, indicating moderate internal consistency. For this study, Cronbach's alpha was .68, showing moderate reliability as well.

The Brazilian version of the Perceived Stress Scale ${ }^{44}$ was used to measure subjects' stress. This instrument is composed of 14 questions answered in a 5-point Likert scale that ranges from $0=$ never to 4 = always. Questions with a positive connotation (4, 5, 6, 7, 9, 10 and 13) are inversely scored before adding the remaining questions. Total score can range from o to 56 and higher values indicate higher levels of stress. The Perceived Stress Scale proved to be a clear and reliable $(\alpha=.82)$ tool to measure the perceived stress of Brazilian elderly, showing suitable psychometric performance ${ }^{44}$. Cronbach's alpha for present study was .74, indicating strong reliability.

Subject's anxiety was assessed through the Brazilian version of the Geriatric Anxiety Inventory ${ }^{45}$. Considered of easy and quick administration, this instrument has 20 items that can be answered with either "agree" (1 point) or "disagree" (o points). Scores above 10/11 points indicate symptoms of anxiety. Martiny et al. ${ }^{45}$ verified satisfactory translation and adaptation of the scale to Portuguese language.

The Brazilian short-version of the Geriatric Depression Scale ${ }^{46}$ was used to verify indicatives of depression. This scale detects depressive symptoms in the elderly and is composed of 15 questions to be answered with either "yes" or "no", points are attributed to every no-answer in questions 1, 5, 7, 11 and 13, or yes-answer in the remaining questions. Scores over 5 points represent indicatives of stress and scores of
11 or above characterize indicatives of severe depression. During the study of the reliability of the scale, Almeida and Almeida ${ }^{46}$ verified that 15 item and 10-item GDS can be used with relative reliability in clinical practice, particularly when considering total scale scores.

\section{Procedures}

The data were collected in 12 UBS, of the 33 UBS of Maringá, divided in four regions (north, south, east and west), selected by lot, after authorization of the Permanent Committee for Formation and Training of Health Workers (CECAPS).

Before the beginning of the data collection, a team of 10 researchers was properly trained, and a pilot test was conducted with 30 older people. The volunteers were approached by the researcher in charge or by the research team. They were informed about the justification, objectives and procedures to be carried out, according to guidelines for research with human beings included in Resolution 196/96 of the National Health Council. After these procedures, those who agreed to participate in the research signed the Informed Consent Form (TCLE). The collection was carried out in different days, shifts and schedules, according to the availability of the researchers.

The direct interview was chosen in the application of the questionnaires, due to the possible difficulty of reading, visual problems and comprehension.

\section{Data Analysis}

Data analysis was conducted through descriptive and inferential statistics. Independent sample t-test was used to test sex differences in life satisfaction and purpose in life. The effect size (d) was also calculated using the model proposed by Cohen ${ }^{47}$, or differences in the values of two independent groups. According to Cohen's criteria, a value up to $d=0.30$ represents small effect size; $d=0.50$, medium; and $d=$ 0.80, large. Pearson Correlation was used to analyze the relationship between indicative of stress, anxiety, depression, life satisfaction and purpose in life. Multiple Regression Analysis was used to determine whether indicative of 
stress, anxiety and depression might predict life satisfaction and purpose in life. Two models were conducted using the backward method to enter the variables (removal criterion $\mathrm{F}=0.10$ ) to investigate the prediction of indicative of stress, anxiety and depression (independent variables) on scores of life satisfaction and purpose in life (dependent variable): life satisfaction (Model 1); and purpose in life (Model 2). All independent variables were included together in the model in the same block. Data were screened to ensure that assumptions of normality, linearity, multicollinearity, and homogeneity of variancecovariance matrices were met ${ }^{48}$. Data showed normal distribution and variances were equal. There were no sufficiently strong correlations between variables that indicate problems with multicollinearity (Variance Inflation Factors <5.0). All analysis were performed at SPSS v.22.0.

\section{Results}

\section{Preliminary analyses}

From the 654 older adults evaluated, prevailed women (56.0\%), married (61.3\%), aged between 60 and 69 years (59.2\%), monthly income between one and two minimum wages (70.0\%), Caucasian (81.0\%) and retired (75.0\%). It was also observed that most of them had incomplete primary education (43.0\%).

\section{Descriptive statistics and sex differences}

Descriptive statistics of study variables are presented in Table 1. Skewness and kurtosis revealed normal distribution of the data. Mean scores for life satisfaction and purpose in life were moderate to high, indicatives of anxiety and depression were below the cut point on average and moderate stress levels were found.

Table 1 - Descriptive values (minimum, maximum, mean, standard deviation, skewness and kurtosis) of the variables.

\begin{tabular}{|c|c|c|c|c|c|}
\hline Variables & Minimum & Maximum & $x(s d)$ & Skewness & Kurtosis \\
\hline Indicative of Stress & 2.00 & 48.00 & $22.42(7.53)$ & 0.08 & 0.35 \\
\hline Indicative of Anxiety & 0.00 & 20.00 & $5.60(3.54)$ & 0.91 & -0.13 \\
\hline Indicative of Depression & 0.00 & 13.00 & $3.74(2.15)$ & 0.68 & -0.59 \\
\hline Life Satisfaction & 11.00 & 35.00 & $26.06(4.43)$ & -0.88 & 0.97 \\
\hline Purpose in life & 1.20 & 5.00 & $3.32(0.57)$ & -0.41 & 0.72 \\
\hline
\end{tabular}

Note. $\mathrm{x}=$ mean; $\mathrm{sd}=$ standard deviation.

Sex differences are shown on Table 2. Males and females did not differ significantly in their levels of life satisfaction, purpose in life and indicatives of depression. On the other hand, older women presented higher levels of indicatives of stress $(+5.6 \%)$ and anxiety (+29\%) when compared to older men $(p<0.05)$.

Table 2 - Sex Differences in indicative of stress, depression, anxiety, life satisfaction and purpose in life.

\begin{tabular}{|c|c|c|c|c|c|}
\hline \multirow{2}{*}{ Variables } & Male $(n=288)$ & Female $(n=366)$ & \multirow{2}{*}{$\mathbf{t}$} & \multirow{2}{*}{ p } & \multirow{2}{*}{ d } \\
\hline & $\mathrm{x} \pm \mathrm{SD}$ & $\mathrm{x} \pm \mathrm{SD}$ & & & \\
\hline Indicative of Stress & $21.70 \pm 7.81$ & $22.98 \pm 7.27$ & -2.162 & $0.031^{*}$ & -0.17 \\
\hline Indicative of Anxiety & $4.55 \pm 3.82$ & $6.42 \pm 4.92$ & -4.462 & $0.001^{*}$ & -0.42 \\
\hline Indicative of Depression & $3.56 \pm 2.16$ & $3.89 \pm 2.14$ & -1.338 & 0.181 & -0.15 \\
\hline Life Satisfaction & $26.34 \pm 4.12$ & $25.84 \pm 4.65$ & 1.455 & 0.146 & 0.06 \\
\hline Purpose in life & $3.34 \pm 0.60$ & $3.31 \pm 0.55$ & 0.671 & 0.503 & 0.05 \\
\hline
\end{tabular}


Relationship between indicatives of stress depression, anxiety, life satisfaction and purpose in life

Following sex differences, Pearson Correlation Analysis were conducted separately for male and female subjects, and results are presented in Table 3. Life satisfaction was inversely correlated to stress (Male, $r=-0.44 /$ Female, $r=-0.42$ ), anxiety (Male, $r=-0.33$ /Female, $r=-0.21$ ), and depression
(Male, $r=-0.34 /$ Female, $r=-0.41$ ). Purpose in life also presented a negative correlation with stress (Male, $r=-0.28 /$ Female, $r=-0.33$ ), anxiety (Male, $r$ $=-0.20 /$ Female, $r=-0.19$ ) and depression (Male, $r=-0.37 /$ Female, $r=-0.39$ ). All correlations were significant $(p<0.05)$. It is important to highlight that some correlations were weak $(r<.40)$.

Table 3 - Correlation of indicative of stress, anxiety and depression with life satisfaction and purpose in life.

\begin{tabular}{lcccc}
\hline \multirow{2}{*}{ Variables } & \multicolumn{2}{c}{ Life Satisfaction } & \multicolumn{2}{c}{ Purpose in life } \\
\cline { 2 - 4 } & Male $(\mathrm{n}=\mathbf{2 8 8})$ & Female $(\mathrm{n}=\mathbf{3 6 6})$ & Male $(\mathbf{n}=\mathbf{2 8 8})$ & Female $(\mathbf{n}=\mathbf{3 6 6})$ \\
\hline Indicative of Stress & $-0.44^{*}$ & $-0.42^{*}$ & $-0.28^{*}$ & $-0.33^{*}$ \\
Indicative of Anxiety & $-0.33^{*}$ & $-0.21^{*}$ & $-0.20^{*}$ & $-0.19^{*}$ \\
Indicative of Depression & $-0.34^{*}$ & $-0.41^{*}$ & $-0.37^{*}$ & $-0.39^{*}$ \\
\hline
\end{tabular}

Note. ${ }^{*} \mathrm{p}<0.05$.

Then, multiple regression analysis were conducted in order to determine the role of indicatives of stress, anxiety and depression in predicting life satisfaction (Table 4) and purpose in life (Table 5), since we observed that strength of correlations did not vary significantly between males and females, regression analysis were performed for the overall sample.

Results revealed that Model $1^{\text {b }}$ showed greater percentage of explained variance of life satisfaction (Table 4 ). Indicative of stress and depression ( $R=0.55 ; R^{2}=0.31 ; F=142.004 ; P<0.01$ ) were significant predictors of life satisfaction in $31 \%$ of its variance, with both stress $(\beta=-0.29$; $p=0.001$ ) and depression ( $\beta=-0.36 ; p=0.001$ ) having a negative and moderate association with life satisfaction, while indicatives of anxiety did not enter the final model $(p=0.394)$.

Table 4 - Multiple Regression Analysis using indicative of stress, anxiety and depression as predictors of life satisfaction.

\begin{tabular}{|c|c|c|c|}
\hline Models & Standardized $\beta$ & Adjusted $\mathbf{R}^{2}$ & $p$ \\
\hline \multicolumn{4}{|l|}{ Model $1^{\mathrm{a}}$} \\
\hline Indicative of Stress & -0.30 & & $0.001^{*}$ \\
\hline Indicative of Anxiety & 0.03 & 0.30 & 0.394 \\
\hline Indicative of Depression & -0.37 & & $0.001^{*}$ \\
\hline \multicolumn{4}{|l|}{ Model $1^{\mathrm{b}}$} \\
\hline Indicative of Stress & -0.29 & & $0.001^{*}$ \\
\hline Indicative of Depression & -0.36 & 0.31 & $0.001^{*}$ \\
\hline
\end{tabular}

Note. ${ }^{*} \mathrm{p}<0.05$.

For purpose in life, results from Model 2 (Table 5) showed indicative of stress, anxiety and depression $\left(R=0.43 ; R^{2}=0.18 ; F=47.727 ; p<0.01\right)$ to be significant predictors of $18 \%$ of purpose-in-life's explained variance. The relationship of indicative of stress ( $\beta=-$ $0.15 ; p=0.001$ ) and depression ( $\beta=-0.39 ; p=0.001$ ) with purpose in life was negative, while anxiety $(\beta=0.10$; $\mathrm{p}=0.036$ ) showed a positive, yet weak association. 
Table 5 - Multiple Regression Analysis using indicative of stress, anxiety and depression as predictors of purpose in life.

\begin{tabular}{lccc}
\multicolumn{1}{c}{ Models } & Standardized $\beta$ & Adjusted R & p \\
\hline Model 2 & & & \\
Indicative of Stress & -0.15 & $0.001^{*}$ \\
Indicative of Anxiety & 0.10 & 0.18 & $0.036^{*}$ \\
Indicative of Depression & -0.39 & $0.001^{*}$ \\
\hline
\end{tabular}

Note. ${ }^{*} \mathrm{p}<0.05$.

\section{Discussion}

To the best of our knowledge, this is the first study to analyze the role of indicative of stress, anxiety and depression in predicting life satisfaction and purpose in life among elderly. Our results showed that indicatives of stress and depression are significant predictors of lower levels of both life satisfaction and purpose in life, while anxiety did not impact satisfaction and had a positive association to purpose in life. Moreover, despite showing higher levels of stress and anxiety when compared to men, elderly women did not differ in their levels of life satisfaction and purpose in life.

Stress and depression had a significant and negative impact over older adults' life satisfaction and purpose in life. Life satisfaction variance was explained in $31 \%$ by indicatives of stress and depression (Model 1b), while purpose in life variance was explained in $18 \%$ by all three independent variables (Model 2), indicating that stress and depression have a greater impact over one's life satisfaction compared to its negative effect over purpose in life. Considering the strength of associations, depression was the most significant hindering factor for both elderly life satisfaction and purpose in life, while stress had a stronger effect over life satisfaction than it did on purpose in life.

Similar to our results, a cross-sectional study by Mhaolain et al. ${ }^{16}$ also found through multivariate regression analysis that depression was a predictor of lower satisfaction with life. In contrast, a longitudinal study adopting path analysis by Guo ${ }^{35}$ did not find a significant effect of depression on life satisfaction; however, they found that wife's depression predicted lower husband's life satisfaction after a 4-year follow up. Other studies have also reported negative correlations between depressive symptoms and life satisfaction ${ }^{25.33-36}$. Other studies have also found a negative relationship between depression and purpose in life ${ }^{38,41,49}$, highlighting depression as a potential hindering factor for both life satisfaction and purpose in life.

Quantitative evidence regarding the association between stress and life satisfaction in older adults is still scarce, however, our findings contrasted results from Hannaford et al. ${ }^{25}$ who found that stressful life events did not predict life satisfaction. Our results also differed from a study by Hamarat et al. ${ }^{37}$ on which stress did not predict life satisfaction of older adults, yet these authors accounted for effectives of coping resources, a factor that may balance out the effects of stress and significantly predicted life satisfaction in their model. No other study assessed stress' impact over purpose in life of the elderly ${ }^{39}$, our results suggest that stress may have a mild yet significant negative influence over purpose in life.

On the other hand, anxiety was the most discrepant from all three measures. Indicatives of anxiety were not a significant predictor of life satisfaction when accounting for stress and depression, besides, it presented a positive association with purpose in life. Investigations analyzing anxiety as a predictor of life satisfaction are scarce, but studies found a negative correlation between anxiety and life satisfaction ${ }^{25}$ and purpose in life, similar to our results (Table 3), which differed 
after multivariate analysis. A possible explanation is that levels of anxiety were low for both elderly men and women, thus, they could have been not high enough to produce significant negative outcomes, especially when accounting for stress and depression, besides, low levels of anxiety still produce some level of physiological arousal through its somatic responses ${ }^{50}$, which may have positive consequences by stimulating the individual.

The purpose of life can also be considered a factor that helps in coping with situations considered adverse for the elderly. Life purpose and life satisfaction can make individuals less vulnerable to changes in stress.

In our study, we found no differences between sexes for levels of life satisfaction, purpose in life and indicatives of depression, however, older women showed higher levels of indicatives of stress and anxiety when compared to older men. A previous investigation found that women had lower scores of purpose in life compared to men, and that, after 5 years, older women (but not older men) had experienced a significant decline in scores ${ }^{51}$. As for life satisfaction, older men appear to present a higher life satisfaction than older women. A recent study conducted with both sexes showed that men are happier than women, a difference that becomes more pronounced with age, and older men reach their minimum life satisfaction level earlier than women ${ }^{52}$.

Present findings should be interpreted in consideration of our limitations. The cross-sectional design of our study means that no conclusion about cause-effect can be drawn. Although evidences were drawn from only one city in the south region of Brazil, studied data referred to very general concepts of life (i.e. satisfaction, purpose in life, stress, anxiety and depression); however, socioeconomic and cultural factors that may influence these factors were not accounted for. There is indicative on literature that socioeconomic conditions and education by the time the person answered the questionnaires used in this study may play an important role (i.e. older adults with better monthly income use to present higher life satisfaction). Some researchers found that life satisfaction in older people is determined by poor overall health, and especially by poor financial resources 53.54 . Thus, future studies could advance current knowledge by comparing different cultures, socioeconomic statuses, and education, or assessing how levels of depression would predict life satisfaction and purpose in life in a longitudinal design, another suggestion is to test the effects of different types of interventions over older adults' depression, while taking life satisfaction and purpose in life in consideration.

Based on the findings, it can be concluded that indicative of stress, anxiety and depression may predict both life satisfaction and purpose in life in older adults. Specifically, indicative of stress and depression may negatively predict both life satisfaction and purpose in life, while anxiety may be considered a positive predictor for purpose in life when levels of anxiety are low. From a practical standpoint, improving symptoms of depression seems to be the primary target for increasing both satisfaction with life and purpose in life of the elderly men and women, especially considering this population's increased risk for depression. Strategies and initiatives to treat depression in older adults will have a great potential for enhancing these individuals' life satisfaction and purpose in life, which are very likely to lead to other positive outcomes as well.

\section{References}

1. World Health Organization. World report on disability 2011 [Internet]; 2011. Available from: https://www.who. int/disabilities/world_report/2011/report.pdf

2. Instituto Brasileiro de Geografia e Estatística. Projeção da população do Brasil e das Unidades da Federação [Internet]; 2016 [citado 28 dez. 2016]. Disponivel em: http://www.ibge. gov.br/apps/populacao/projecao

3. Cruz-Jentoft AJ, Baeyens JP, Bauer JM, Boirie $Y$, Cederholm T, Landi F, et al. Sarcopenia: European consensus on definition and diagnosisReport of the European Working Group on Sarcopenia in Older People. Age ageing. 2010;39(4):412-23. https://dx.doi. org/10.1093/ageing/afq034

4. Cesari M, Rolland Y, Abellan Van Kan G, Bandinelli S, Vellas B, Ferrucci L. Sarcopenia-related parameters and incident disability in older persons: results from the "invecchiare in Chianti" study. J Gerontol A Biol Sci Med. 2014:70(4):457-63. https://dx.doi.org/10.1093/ gerona/glu181 
5. Pagotto V, Silveira EA. Applicability and agreement of different diagnostic criteria for sarcopenia estimation in the elderly. Arch Gerontol Geriatr. 2014;59(2):288-94. https://dx.doi.org/10.1016/j.archger.2014.05.009

6. Pereira FB, Leite AF, Paula APd. Relationship between pre-sarcopenia, sarcopenia and bone mineral density in elderly men. Arch Endocrinol Metab. 2015:59(1):5965. https://dx.doi.org/10.1590/2359-3997000000011

7. Lang T, Streeper T, Cawthon P, Baldwin K, Taaffe DR, Harris T. Sarcopenia: etiology, clinical consequences, intervention, and assessment. Osteoporos Int. 2010;21(4):54359. https://dx.doi.org/10.1007/s00198-009-1059-y

8. Ribeiro CC, Neri AL, Yassuda MS. Semantic-cultural validation and internal consistency analysis of the Purpose in Life Scale for brazilian older adults. Dement neuropsychol. 2018:12(3):244-9. https://dx.doi. org/10.1590/1980-57642018dn12-030004

9. Pan A, Sun Q, Okereke OI, Rexrode KM, Hu FB. Depression and risk of stroke morbidity and mortality: a meta-analysis and systematic review. Jama. 2011:306(11):1241-9. https://dx.doi.org/10.1001/jama.2011.1282

10. Zhou J. Improving older people's life satisfaction via social networking site use: Evidence from China. Australas J Ageing. 2018:37(1):E23-E8. https://dx.doi. org/10.1111/ajag.12499

11. Jeste DV, Palmer BW, Rettew DC, Boardman S. Positive psychiatry: its time has come. J Clin Psychiatry. 2015:76(6):675. https://dx.doi.org/10.4088/JCP.14nr09599

12. Berg CA, Smith TW, Henry NJ, Pearce GE. A developmental approach to psychosocial risk factors and successful aging. In Aldwin CM, Park CL, Spiro A. III, editors. Handbook of health psychology and aging Handbook of health psychology and aging. New York: Guilford Press; 2007. p. 30-53.

13. Heo J, Stebbins RA, Kim J, Lee I. Serious leisure, life satisfaction, and health of older adults. Leisure Sci. 2013:35(1):1632. https://dx.doi.org/10.1080/01490400.2013.739871

14. Rodgers V, Neville S, La Grow S. Health, functional ability and life satisfaction among older people 65 years and over: a cross-sectional study. Contemp Nuerse. 2017:53(3):28492. https://dx.doi.org/10.1080/10376178.2017.1319286

15. George LK. Still happy after all these years: Research frontiers on subjective well-being in later life. J Gerontol B Psychol Sci Soc Sci. 2009;65(3):331-9. https://dx.doi. org/10.1093/geronb/gbq006

16. Mhaoláin AMN, Gallagher D, Connell HO, Chin A, Bruce I, Hamilton F, et al. Subjective well-being amongst community-dwelling elders: what determines satisfaction with life? Findings from the Dublin Healthy Aging Study. Int Psychogeriatr. 2012;24(2):316-23. https:// dx.doi.org/10.1017/S1041610211001360

17. Ngoo YT, Tey NP, Tan EC. Determinants of life satisfaction in Asia. Social Indicators Research. 2015;124(1):14156. https://dx.doi.org/10.1007/s11205-014-0772-x

18. Şahin DS, Özer Ö, Yanardağ MZ. Perceived social support, quality of life and satisfaction with life in elderly people. Educ Gerontol. 2019:45(1):69-77. https://dx. doi. org/10.1080/03601277.2019.1585065
19. Lyyra T-M, Törmäkangas TM, Read S, Rantanen T, Berg $\mathrm{S}$. Satisfaction with present life predicts survival in octogenarians. J Gerontol B Psychol Sci Soc Sci. 2006;61(6):31926. https://dx.doi.org/10.1093/geronb/61.6.p319

20. St. John PD, Mackenzie C, Menec V. Does life satisfaction predict five-year mortality in community-living older adults? Aging ment health. 2015;19(4):363-70. https://dx.doi.org/10.1080/13607863.2014.938602

21. Diener E, Chan MY. Happy people live longer: Subjective well-being contributes to health and longevity. Appl Psychol: Health Well-Being. 2011;3(1):1-43. https:// dx.doi.org/10.1111/j.1758-0854.2010.01045.x

22. Steptoe A, Wardle J. Enjoying life and living longer. Arch Intern Med. 2012;172(3):273-5. DOI: 10.1001/archinternmed.2011.1028.

23. Didino D, Taran EA, Gorodetski K, Melikyan ZA, Nikitina S, Gumennikov I, et al. Exploring predictors of life satisfaction and happiness among Siberian older adults living in Tomsk Region. Eur J Ageing. 2018;15(2):175-87. https://dx.doi.org/10.1007/s10433-017-0447-y

24. Gutiérrez M, Tomás J, Galiana L, Sancho P, Cebrià $M$. Predicting life satisfaction of the Angolan elderly: A structural model. Aging Ment Health. 2013;17(1):94101. https://dx.doi.org/10.1080/13607863.2012.702731

25. Hannaford E, Moore F, Macleod FJ. What a difference a year makes: comparing relationships between stressful life events, mood and life satisfaction among older adults, and their working-age counterparts. Aging Ment Health. 2018;22(12):1658-65. https://dx.doi.org/1 $0.1080 / 13607863.2017 .1387761$

26. Harasemiw O, Newall N, Mackenzie CS, Shooshtari $\mathrm{S}$. Menec $\mathrm{V}$. Is the association between social network types, depressive symptoms and life satisfaction mediated by the perceived availability of social support? A cross-sectional analysis using the Canadian Longitudinal Study on Aging. Aging Ment Health. 2018:1-10. https://dx.doi.org/10.1080/13607863.2018.1495176

27. Lee J, Cagle JG. Social exclusion factors influencing life satisfaction among older adults. J Poverty Soc Justice. 2018;26(1):35-50. https://dx.doi.org/10.1332/1 75982717X15127351091521

28. Macia E, Duboz P, Montepare JM, Gueye L. Exploring life satisfaction among older adults in Dakar. J Cross Cult Gerontol. 2015:30(4):377-91. https://dx.doi.org/10.1007/ S10823-015-9275-8

29. Mao X, Han WJ. Living Arrangements and Older Adults' Psychological Well-Being and Life Satisfaction in China: Does Social Support Matter? Family Relat. 2018;67(4):567-84. https://dx.doi.org/10.1111/fare.12326

30. Camacho D, Lee Y, Bhattacharya A, Vargas LX, Kimberly L, Lukens E. High Life Satisfaction: Exploring the Role of Health, Social Integration and Perceived Safety among Mexican Midlife and Older Adults. J Gerontol Soc work. 2019:62(5):1-22. https://dx.doi.org/10.1080/ 01634372.2019 .1621975 
31. Gana K, Bailly N, Saada Y, Joulain M, Trouillet R, Hervé $C$, et al. Relationship between life satisfaction and physical health in older adults: A longitudinal test of cross-lagged and simultaneous effects. Health Psychol. 2013:32(8):896. https://dx.doi.org/10.1037/a0031656

32. Delhom I, Gutierrez M, Lucas-Molina B, Meléndez J. Emotional intelligence in older adults: psychometric properties of the TMMS-24 and relationship with psychological well-being and life satisfaction. Int Psychogeriatr. 2017;29(8):1327-34. https://dx.doi.org/10.1017/ $\underline{\mathrm{S} 1041610217000722}$

33. Celik SS, Celik Y, Hikmet N, Khan MM. Factors affecting life satisfaction of older adults in Turkey. Int J Aging Hum Dev. 2018;87(4):392-414. https://dx.doi. org/10.1177/0091415017740677

34. Dezutter J, Wiesmann U, Apers S, Luyckx K. Sense of coherence, depressive feelings and life satisfaction in older persons: a closer look at the role of integrity and despair. Aging Ment Health. 2013:17(7):839-43. https:// dx.doi.org/10.1080/13607863.2013.792780

35. Guo X. Reciprocal effects of depressive symptoms and life satisfaction among Chinese older married couples from 2010 to 2014: evidence from the China Family Panel Studies. Aging Ment Health. 2019:1-9. https://dx.doi.org/10.1080/13607863.2019.1584876

36. López-Ortega M, Torres-Castro S, Rosas-Carrasco O Psychometric properties of the Satisfaction with Life Scale (SWLS): secondary analysis of the Mexican Health and Aging Study. Health Qual Life Outcomes. 2016;14(1):170-6. https://dx.doi.org/10.1186/s12.955-016-0.573-9

37. Hamarat DT, Karen M. Zabrucky, Don Steele, Kenneth B. Matheny, Ferda Aysan, Errol. Perceived stress and coping resource availability as predictors of life satisfaction in young, middle-aged, and older adults. Exp Aging Res. 2001;27(2):181-96. https://dx.doi.org/ 10.1080/036107301750074051

38. Boyle PA, Barnes LL, Buchman AS, Bennett DA. Purpose in life is associated with mortality among community-dwelling older persons. Psychosom Med. 2009:71(5):574. https://dx.doi.org/10.1097/PSY.0b013e3181a5a7co

39. Irving J, Davis S, Collier A. Aging with purpose: Systematic search and review of literature pertaining to older adults and purpose. Int J Aging Hum Dev. 2017;85(4):40337. https://dx.doi.org/10.1177/0091415017702908

40. Hafez D, Heisler M, Choi H, Ankuda CK, Winkelman T, Kullgren JT. Association between purpose in life and glucose control among older adults. Ann Behav Med. 2018:52(4):309-18. https://dx.doi.org/10.1093/abm/kax012

41. Kim G, Shin SH, Scicolone MA, Parmelee P. Purpose in Life Protects Against Cognitive Decline Among Older Adults. Innov Aging. 2019;27(6):593-601. https://dx.doi. org/10.1093/geroni/igz038.2414

42. Diener E, Emmons RA, Larsen RJ, Griffin S. The satisfaction with life scale. J Personality Assessm. 1985:49(1):71-5

43. Neto F. The satisfaction with life scale: Psychometrics properties in an adolescent sample. J Youth Adolesc. 1993;22(2):125-34.
44. Luft CDB, Sanches SdO, Mazo GZ, Andrade A. Versão brasileira da Escala de Estresse Percebido: tradução e validação para idosos. Rev Saúde Pública. 2007:41:606-15. https://dx.doi.org/10.1590/S0034$\underline{89102007000400015}$

45. Martiny C, Silva ACO, Nardi AE, Pachana NA. Tradução e adaptação transcultural da versão brasileira do Inventário de Ansiedade Geriátrica (GAI). Rev Psychiatr Clin. 2011;38(1):08-12. https://dx.doi.org/10.1590/S010160832011000100003

46. Almeida OP, Almeida SA. Confiabilidade da versão brasileira da Escala de Depressão em Geriatria (GDS) versão reduzida. Arq Neuropsiquiatr. 1999:57(2B):421-6. https://dx.doi.org/10.1590/S0004-282X1999000300013

47. Cohen J. A power primer. Psychological bulletin. 1992:112(1):155-9.

48. Tabachnick BG, Fidell LS. Using multivariate statistics. $5^{\text {a }}$ ed. Upper Saddle River: Pearson Allyn \& Bacon; 2007.

49. Kim H, Thyer BA, Munn JC. The relationship between perceived ageism and depressive symptoms in later life Understanding the mediating effects of self-perception of aging and purpose in life, using structural equation modeling. Educat Gerontol. 2019;45(2):105-19. https:// dx.doi.org/10.1080/03601277.2019.1583403

50. Janelle CM. Anxiety, arousal and visual attention: A mechanistic account of performance variability. J Sports Sci. 2002;20(3):237-51. https://dx.doi. org/10.1080/026404102317284790

51. Hedberg P, Brulin C, Aléx L, Gustafson Y. Purpose in life over a five-year period: a longitudinal study in a very old population. Int Psychogeriatrics. 2011;23(5):806-13. https://doi.org/10.1017/S1041610210002279

52. Kolosnitsyna M., Khorkina N., Dorzhiev H. Determinants of Life Satisfaction in Older Russians. Ageing Int 42, 354373 (2017). https://doi.org/10.1007/s12126-017-9297-3

53. Angelini V, Cavapozzi D, Corazzini L, Paccagnella O. Age, Health and Life Satisfaction Among Older Europeans. Soc indic Res. 2012;105(2):293-308. https://doi. org/10.1007/s11205-011-9882-X.

54. Borg C, Hallberg IR., Blomqvist K. Life satisfaction among older people (65+) with reduced self-care capacity: the relationship to social, health and financial aspects. J Clin Nurs. 2006;15(5), 607-18. https://dx.doi. org/10.1111/j.1365-2702.2006.01375.x

\section{Daniel Vicentini de Oliveira}

Doutor em Gerontologia pela Universidade Estadual de Campinas (UNICAMP), em Campinas, SP, Brasil; mestre em Promoção da Saúde pela Universidade Cesumar (Unicesumar), em Maringá, PR, Brasil; professor da Universidade Cesumar (Unicesumar), em Maringá, PR, Brasil. 


\section{Renan Codonhato}

Mestre em Educação Física pela Universidade Estadual de Maringá (UEM), em Maringá, PR, Brasil; doutorando em Educação Física pela mesma instituição.

\section{Matheus Amarante do Nascimento}

Doutor em Educação Fisica pela Universidade Estadual de Maringá (UEM), em Maringá, PR, Brasil; mestre em Educação Física pela UEM; professor da Universidade do Estado do Paraná (UNESPAR), em Maringá, PR, Brasil.

\section{Braulio Henrique Magnani Branco}

Doutor em Educação Física pela Universidade de São Paulo (USP), em São Paulo, SP, Brasil; mestre em Ciências da Saúde pela Universidade Estadual de Maringá (UEM), em Maringá, PR, Brasil; professor da Universidade Cesumar (Unicesumar), em Maringá, PR, Brasil.

\section{Gabriel Lucas Morais Freire}

Mestre em Educação Física pela Universidade Federal do Vale do São Francisco (UNIVASF), em Petrolina, PE, Brasil; doutorando em Educação Física pela Universidade Estadual de Maringá (UEM), em Maringá, PR, Brasil;

\section{José Roberto Andrade do Nascimento Júnior}

Doutor e mestre em Educação Fisica pela Universidade Estadual de Maringá (UEM), em Maringá, PR, Brasil; professor da Universidade Federal do Vale do São Francisco (UNIVASF), PE, Brasil.

\section{Lenamar Fiorese}

Doutora e mestre em Ciência do Movimento Humano pela Universidade Federal de Santa Maria (UFSM), Santa Maria, RS, Brasil; professora da Universidade Estadual de Maringá (UEM), em Maringá, PR Brasil.

\section{Mailing address}

Daniel Vicentini de Oliveira

Universidade Cesumar

Av. Guedner, 1610, bloco 7

Jardim Aclimação, 87050-900

Maringá, PR, Brasil 